\title{
Genome-wide scan for bovine milk-fat composition. I. Quantitative trait loci for short- and medium-chain fatty acids
}

\author{
W. M. Stoop, ${ }^{* 1,2}$ A. Schennink, ${ }^{* 2}$ M. H. P. W. Visker, ${ }^{*}$ E. Mullaart, $†$ J. A. M. van Arendonk, ${ }^{*}$ and H. Bovenhuis ${ }^{*}$ \\ ${ }^{*}$ Animal Breeding and Genomics Centre, Wageningen University, PO Box 338, 6700 AH Wageningen, the Netherlands \\ †CRV, $6802 \mathrm{~EB}$, Arnhem, the Netherlands
}

\section{ABSTRACT}

A genome-wide scan was performed to identify quantitative trait loci (QTL) for short- and medium-chain fatty acids (expressed in wt/wt \%). Milk samples were available from 1,905 cows from 398 commercial herds in the Netherlands, and milk-fat composition was measured by gas chromatography. DNA was available from 7 of the paternal half-sib families: 849 cows and their 7 sires. A genetic map was constructed comprising 1,341 SNP and 2,829 cM, with an average information content of 0.83. Multimarker interval mapping was used in an across-family regression on corrected phenotypes for the 7 half-sib families. Four QTL were found: on Bos taurus autosome (BTA) 6, a QTL was identified for $\mathrm{C} 6: 0$ and $\mathrm{C} 8: 0$; on BTA14, a QTL was identified for fat percentage, all odd-chain fatty acids, and C14:0, C16:0, C16:1, and their unsaturation indices; on BTA19, a QTL affected C14:0; and on BTA26, a QTL was identified for the monounsaturated fatty acids and their unsaturation indices. The QTL explained 3 to $19 \%$ of phenotypic variance. Furthermore, 49 traits with suggestive evidence for linkage were found on 21 chromosomes. Additional analyses revealed that the QTL on BTA14 was most likely caused by a mutation in DGAT1, whereas the QTL on BTA26 was most likely caused by a mutation in the $S C D 1$ gene. Quantitative trait loci that affect specific fatty acids might increase the understanding of physiological processes regarding fat synthesis and the position of the causal genes.

Key words: genome-wide scan, quantitative trait locus, fatty acid, dairy cattle

\section{INTRODUCTION}

Changing milk fatty acid proportions to a milkfat composition that contributes to improved human

Received December 11, 2008.

Accepted April 27, 2009.

${ }^{1}$ Corresponding author: Marianne.Stoop@crv4all.com

${ }^{2}$ Contributed equally to this paper. health has received considerable attention in the last years (Jensen, 2002; German and Dillard, 2006; Soyeurt et al., 2006, 2007; Vlaeminck et al., 2006; Stoop et al., 2008).

Short- and medium-chain C4 to C17 saturated and monounsaturated milk fatty acids (FA) are largely synthesized de novo in the mammary gland. Saturated even-chain C4:0 to C16:0 FA are synthesized from C2 and $\mathrm{C} 4$ precursors. For C16:0, about 50\% comes from de novo synthesis in the mammary gland and $50 \%$ from blood. Odd-chain FA are mainly derived from rumen bacteria and partly from de novo synthesis from C3 precursors. Monounsaturated FA are suggested to originate from $\Delta^{9}$-desaturase enzyme activity (MacGibbon and Taylor, 2006). Several studies showed genetic variation in milk FA proportions (Soyeurt et al., 2007; Bobe et al., 2008; Stoop et al., 2008). Stoop et al. (2008) showed substantial genetic variation in FA, with intraherd heritabilities ranging from 0.22 to 0.71 . Identifying the genes responsible for this genetic variation is expected to contribute greatly to our understanding of milk FA synthesis and to enhance opportunities to improve milk-fat composition through selective breeding.

Several studies have looked at the effects of genes that are expected to play a role in milk-fat synthesis (Clarke, 1993; Falaki et al., 1997; Stephens et al., 1999; Brym et al., 2004; Cohen et al., 2004; Schnabel et al., 2005; Roy et al., 2006b; Viitala et al., 2006; Khatib et al., 2007; Morris et al., 2007). Although many of these studies found an effect on fat percentage or fat yield, results on milk-fat composition are very limited. Recent studies found significant effects of the diacylglycerol acyltransferase 1 (DGAT1) K232A mutation (Schennink et al., 2007) and of the stearoyl-coenzyme A desaturase 1 (SCD1) A293V mutation (Schennink et al., 2008). However, these 2 genes explain only part of the genetic variation in milk-fat composition, and it is expected that more genes are involved.

Our aim was to identify QTL for fatty acid composition of bovine milk by performing a genome-wide scan. This paper presents results for short- and mediumchain FA. The accompanying paper by Schennink et al. (2009) presents results for long-chain FA. 


\section{MATERIALS AND METHODS}

\section{Phenotypes}

This study was part of the Dutch Milk Genomics Initiative, which focuses on genetic aspects of milk composition. To study milk-fat composition, milk samples were available from 1,905 cows from 398 commercial herds in the Netherlands. Cows descended from 1 of 5 proven bulls $(\mathrm{n}=871), 1$ of 50 young bulls $(\mathrm{n}=844)$, or 1 of 46 other proven bulls $(\mathrm{n}=190)$. The latter group ensured 3 sampled cows per farm. Each cow was more than $87.5 \%$ Holstein-Friesian, was between d 63 and 282 of first lactation, and was milked twice a day. One morning milk sample of $500 \mathrm{~mL}$ per cow was collected in the winter of 2005. Sample bottles contained sodium azide $(0.03 \mathrm{wt} / \mathrm{wt} \%)$ for conservation. Milk-fat composition was measured by gas chromatography at the laboratory of the Netherlands Controlling Authority for Milk and Milk Products (Leusden, the Netherlands) as described by Schennink et al. (2007) and Stoop et al. (2008). The FA were measured as weight proportion of total fat weight. In this study, data are presented for 24 traits related to short- and mediumchain FA: overall fat percentage; saturated $\mathrm{C} 4$ to $\mathrm{C} 17$ FA; monounsaturated C10:1, C12:1, C14:1, C16:1, and C17:1; and the unsaturation indices of these FA. The unsaturation index is an indication of the activity of the $\Delta^{9}$-desaturase enzyme and was calculated as

$$
\frac{c i s-9 \text { FA }}{c i s-9 \text { FA }+ \text { saturated FA }} \times 100,
$$

(Kelsey et al., 2003); for example,

$$
\frac{\mathrm{C} 14: 1}{\mathrm{C} 14: 1+\mathrm{C} 14: 0} \times 100 .
$$

Percentage of fat was determined from a $10-\mathrm{mL}$ milk subsample by infrared spectroscopy by using a Fouriertransform interferogram (MilkoScan FT 6000, Foss Electric, Hillerød, Denmark) at the certified laboratory of the Milk Control Station (Zutphen, the Netherlands). Intraherd heritabilities were calculated as described by Stoop et al. (2008), based on the 1,905 animals from the current study, instead of the 1,933 animals from Stoop et al. (2008). The 28 missing animals had genotypes that conflicted with milk protein types.

\section{Genotypes, Markers, and Linkage Map}

Blood and semen samples were collected for DNA isolation. For the genome scan, genotypes were available from 7 paternal half-sib families of in total 849 cows and 7 sires. The 7 sires were the 5 proven bulls and 2 of the young bulls from which daughter phenotypes were collected. The 7 half-sib families consisted of 193, 179, 170, 166, 91, 29, and 21 cows, respectively. A total of 1,536 SNP were selected either based on heterozygosity in the sires, as known from previous experiments in the Dutch Holstein-Friesian population by CRV (Arnhem, the Netherlands) or from dbSNP, the National Center for Biotechnology Information SNP database (http:// www.ncbi.nlm.nih.gov/projects/SNP). Genotyping was performed by the GoldenGate assay (Illumina, San Diego, CA). Additionally, genotypes for SCD1 and DGAT1 were available from previous studies. Genotypes for $S C D 1$ were obtained by a SNaPshot assay (Schennink et al., 2008) and genotypes for DGAT1 were obtained by an allelic discrimination method (Schennink et al., 2007). Genotypes of DGAT1 and SCD1 were available for 1,687 out of 1,905 cows.

Of all SNP, 1,341 SNP were successfully incorporated into the linkage map of $2,829 \mathrm{cM}$ that was calculated with CRI-MAP (Green et al., 1990). Full details on the genotypings, SNP, and construction of the linkage map are reported by Schopen et al. (2009). When markers mapped at the same position, they were placed $0.1 \mathrm{cM}$ apart to ensure that all markers were included in the analysis by the QTL program. The resulting map of $2,831 \mathrm{cM}$ was used in the QTL analysis.

\section{QTL Mapping}

Phenotypes were precorrected for the systematic effects of DIM, age at first calving, season of calving, and herd. The effects were estimated using an Animal Model in ASReml (Gilmour et al., 2002) on all 1,905 cows with phenotypes, as described by Schennink et al. (2007) and Stoop et al. (2008). Multimarker interval mapping was used in an across-family regression on the corrected phenotypes for the 7 half-sib families that were genotyped (Knott et al., 1996). The regression was performed for each trait and each chromosome by using the following regression model (Spelman et al., 1996):

$$
\mathrm{Y}_{\mathrm{ijk}}=\mu+\mathrm{s}_{\mathrm{i}}+\mathrm{b}_{\mathrm{ik}} \mathrm{X}_{\mathrm{ijk}}+\mathrm{e}_{\mathrm{ijk}},
$$

where $Y_{\mathrm{ijk}}$ is the corrected phenotypic observation for daughter $\mathrm{j}$ nested within sire $\mathrm{i}$ at position $\mathrm{k}, \mu$ is the overall mean, $s_{i}$ is the fixed effect of sire $i, b_{i k}$ is the regression coefficient for sire $\mathrm{i}$ at position $\mathrm{k}, \mathrm{X}_{\mathrm{ijk}}$ is the probability of daughter $\mathrm{j}$ inheriting gamete 1 from sire $i$ at position $k$, and $e_{i j k}$ is the random residual effect for daughter $\mathrm{j}$ nested within sire $\mathrm{i}$ at position $\mathrm{k}$.

Significance thresholds were calculated by permutation testing (Churchill and Doerge, 1994). Chromosome-wise significance levels $\left(P_{\text {chromosome }}\right)$ were obtained 
Table 1. Mean proportion, phenotypic SD $\left(\sigma_{\mathrm{P}}\right)$, and intraherd heritability $\left(\mathrm{h}^{2}\right)$ and standard error (subscript) of short- and mediumchain fatty acids (FA) and unsaturation indices, measured on 1,905 cows $^{1}$

\begin{tabular}{|c|c|c|c|}
\hline Trait & Mean (wt/wt\%) & $\sigma_{\mathrm{P}}$ & $\mathrm{h}_{\mathrm{SE}}^{2}$ \\
\hline C4:0 & 3.50 & 0.24 & $0.44_{0.09}$ \\
\hline C5:0 & 0.03 & 0.01 & $0.14_{0,05}$ \\
\hline C6:0 & 2.22 & 0.14 & $0.47_{0.10}$ \\
\hline C7:0 & 0.03 & 0.01 & $0.17_{0.07}$ \\
\hline C8:0 & 1.37 & 0.12 & $0.61_{0.11}$ \\
\hline C9:0 & 0.04 & 0.02 & $0.25_{0.08}$ \\
\hline C10:0 & 3.03 & 0.35 & $0.72_{0.12}$ \\
\hline C11:0 & 0.08 & 0.03 & $0.34_{0.09}$ \\
\hline C12:0 & 4.11 & 0.46 & $0.64_{0.11}$ \\
\hline C13:0 & 0.11 & 0.04 & $0.19_{0.07}$ \\
\hline C14:0 & 11.61 & 0.78 & $0.62_{0.11}$ \\
\hline C15:0 & 1.17 & 0.16 & $0.30_{0.08}$ \\
\hline C16:0 & 32.59 & 2.15 & $0.43_{0.11}$ \\
\hline $\mathrm{C} 17: 0$ & 0.45 & 0.04 & $0.33_{0.09}$ \\
\hline C10:1 & 0.37 & 0.06 & $0.34_{0,09}$ \\
\hline C12:1 & 0.12 & 0.02 & $0.38_{0.09}$ \\
\hline C14:1 & 1.36 & 0.23 & $0.34_{0.08}$ \\
\hline C16:1 & 1.44 & 0.30 & $0.44_{0.09}$ \\
\hline C17:1 & 0.18 & 0.03 & $0.43_{0.10}$ \\
\hline C10 index ${ }^{2}$ & 10.89 & 1.76 & $0.37_{0.09}$ \\
\hline C12 index & 2.74 & 0.49 & $0.36_{0.09}$ \\
\hline C14 index & 10.51 & 1.68 & $0.45_{0.09}$ \\
\hline C16 index & 4.24 & 0.76 & $0.47_{0.09}$ \\
\hline C17 index & 28.29 & 2.58 & $0.47_{0.10}$ \\
\hline Fat $\%$ & 4.36 & 0.64 & $0.49_{0.10}$ \\
\hline
\end{tabular}

${ }^{1}$ Individual $\mathrm{FA}$ in this table sum to $63.8 \mathrm{wt} / \mathrm{wt} \%$. Other $\mathrm{FA}$ include branched-chain FA (no results shown) and long-chain FA (see Schennink et al., 2009).

${ }^{2}$ The unsaturation index was calculated as $\frac{\text { cis-9 FA }}{\text { cis-9 FA }+ \text { saturated FA }} \times 100$.

by 10,000 permutations. Genome-wise significance levels $\left(P_{\text {genome }}\right)$ were derived from the chromosome-wise significance levels using a Bonferroni correction (De Koning et al., 1998): $P_{\text {genome }}=1-\left(1-P_{\text {chromosome }}\right)^{1 / \mathrm{r}}$, where $\mathrm{r}$ is the ratio of the chromosome length over the genome length. Significant linkage was declared at the $5 \%$ genome-wise significance threshold, and suggestive linkage was declared at the $5 \%$ chromosome-wise significance threshold (Lander and Kruglyak, 1995). The confidence interval for the most likely QTL position was based on 1,000 bootstraps (Visscher et al., 1996). Allele substitution effects were estimated for the significant QTL within each of the 7 families at the most likely QTL position from model [1] using SAS, version 9.1 (SAS Institute, 2004).

Additional analyses were done to investigate whether the effects of polymorphisms in the DGAT1 and SCD1 genes could explain the QTL detected in this study. For this analysis, phenotypes were additionally corrected for the DGAT1 K232A as well as the SCD1 A293V genotypes by including these as fixed effects in the Animal Model. Subsequently, the QTL regression was rerun for all adjusted trait values.

\section{RESULTS}

Table 1 shows the average weight proportion (wt/ wt\%) and intraherd heritability of the included FA and indices.

\section{QTL}

Quantitative trait loci for short- and medium-chain FA were identified on 21 chromosomes in this study and are summarized in Table 2. All QTL that exceeded the threshold for suggestive linkage $\left(P_{\text {chromosome }}<0.05\right)$ are reported. Significant statistical evidence $\left(P_{\text {genome }}<\right.$ 0.05 ) for QTL was found for 23 traits on 4 distinct chromosomal regions on Bos taurus autosome (BTA) 6, BTA14, BTA19, and BTA26. Figures 1 to 4 show the graphs with test statistic distributions for these 4 chromosomes; for BTA14 and BTA26, only a selection of the significant traits is shown (see Table 2 for all traits). Allele substitution effects for significant QTL are shown in Table 3. Results are reported and discussed per chromosome.

On BTA6, a significant QTL near $55 \mathrm{cM}$ affected C6:0 and C8:0 (Table 2, Figure 1). The QTL on BTA6 significantly segregated within families 1,5 , and 6 , with an effect of about 0.5 phenotypic SD (Table 3 ). In family 1 , the difference between the 2 daughter groups was 0.08 (wt/wt\%) for C6:0, and 0.07 (wt/wt\%) for C8:0. In family 5 , the difference for C6:0 was 0.05 (wt/wt\%), but was not significant, whereas the difference for C8:0 was also 0.07 (wt/wt\%). In family 6 , the difference for C6:0 was 0.10 (wt/wt\%). The QTL explained approximately $3 \%$ of the phenotypic variation for both C6:0 and $\mathrm{C} 8: 0$.

On BTA14, a significant QTL at the centromeric end of the chromosome affected all odd-chain FA and C14:0, C16:0, and C16:1, with their unsaturation indices (Table 2, Figure 2). The allele that positively affected C14:0 had a negative effect on the other traits (Table 3 ). The size of the QTL effect was generally 0.5 to 1 phenotypic SD (Table 3). Sires of families 1, 2, 3, 4, and 7 were heterozygous for the QTL. The QTL explained between 3 and $19 \%$ of phenotypic variance for the different traits. This QTL also affected several long-chain FA and the total ratio of saturated and unsaturated FA (Schennink et al., 2009). This QTL mapped to the approximate location of the DGAT1 gene.

On BTA19, a significant QTL was found for C14:0 (60 cM; Table 2, Figure 3). The QTL on BTA19 segregated significantly within families 2,4 , and 7 , with an 
Table 2. Location and characteristics of suggestive and significant QTL affecting short- and medium-chain fatty acids, unsaturation indices, and fat percentage

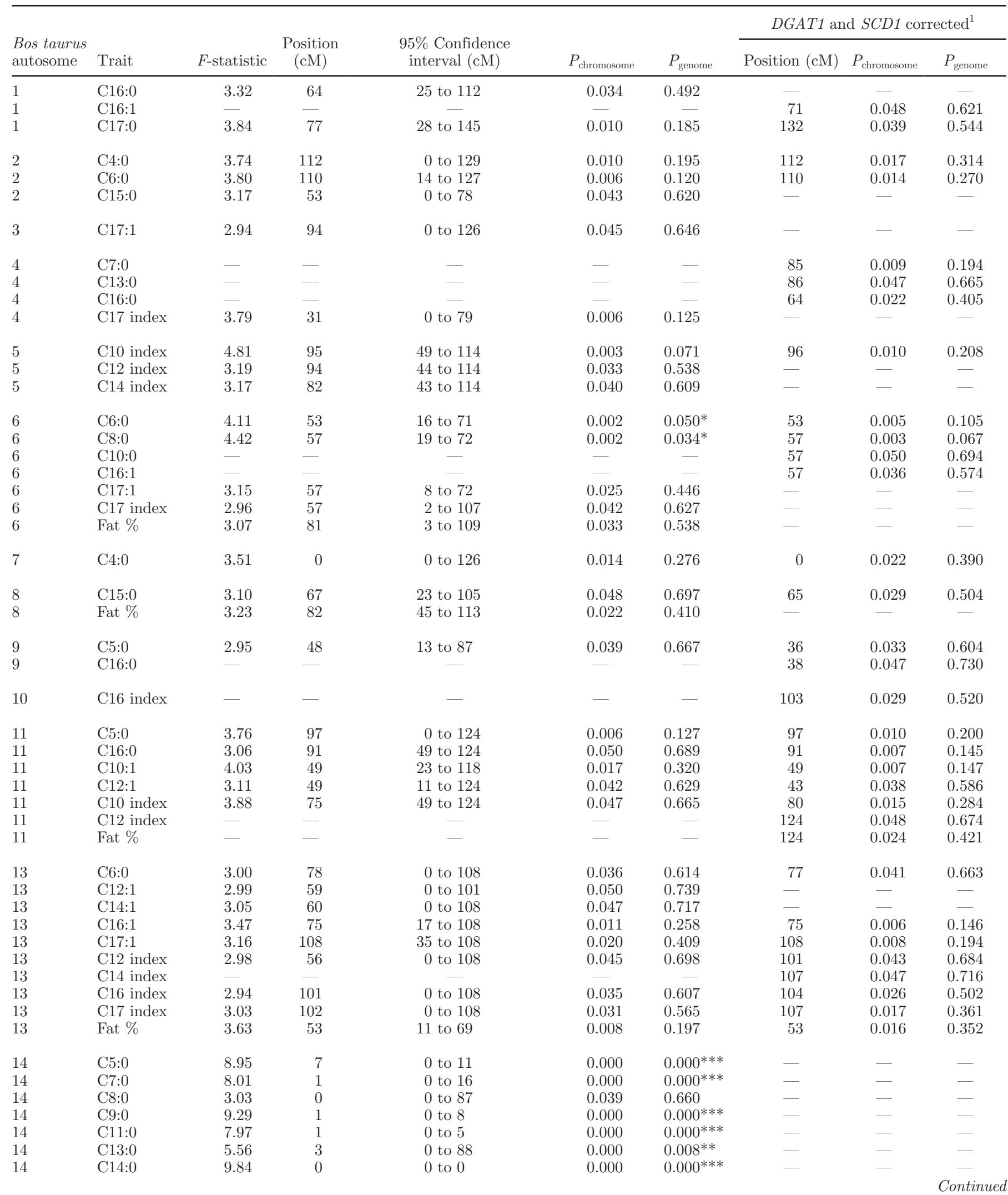


Table 2 (Continued). Location and characteristics of suggestive and significant QTL affecting short- and medium-chain fatty acids, unsaturation indices, and fat percentage

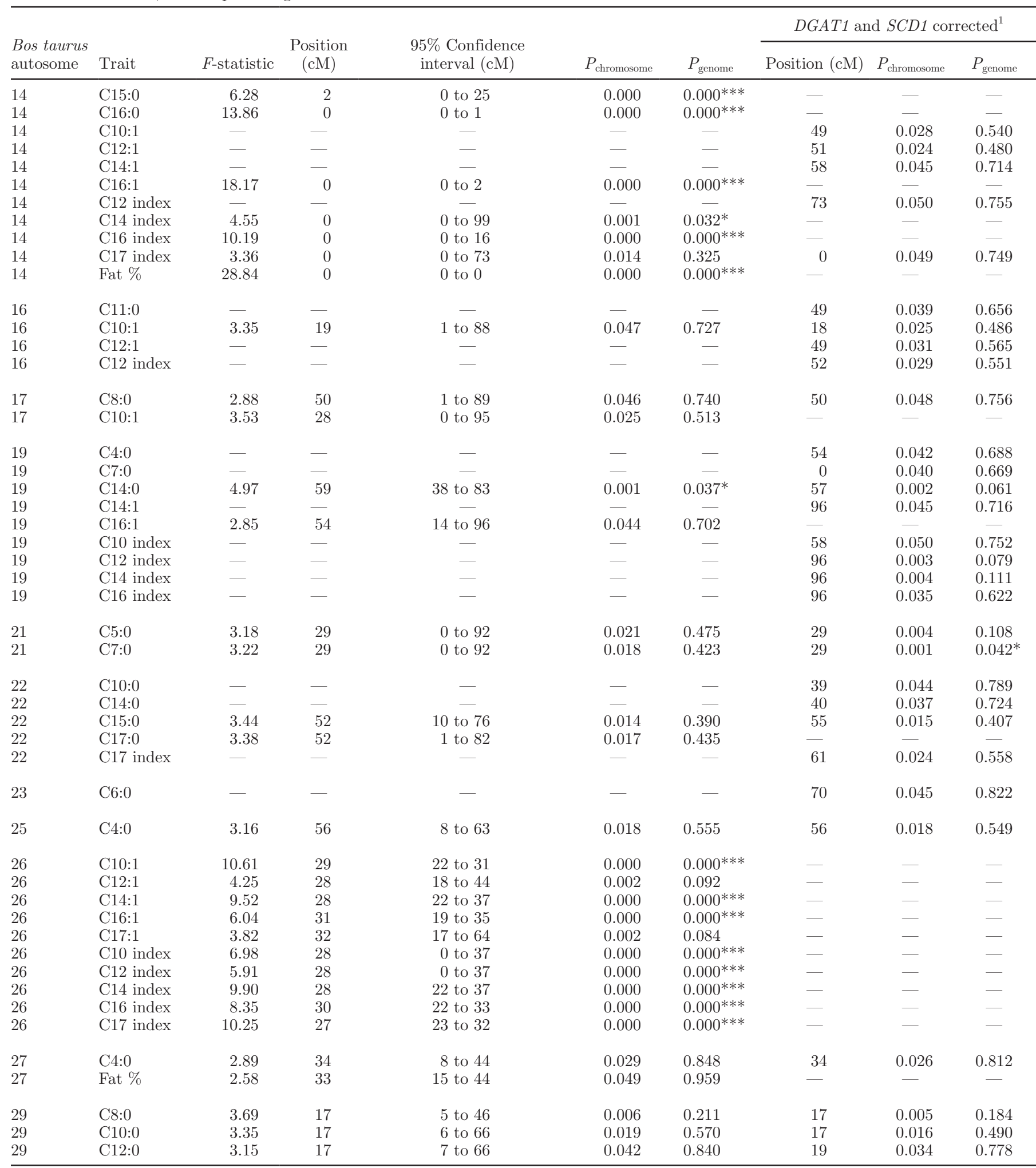

${ }^{1} D G A T 1=$ diacylglycerol acyltransferase $1 ; S C D 1=$ stearoyl-coenzyme A desaturase 1.

${ }^{*} P_{\text {genome }} \leq 0.05,{ }^{* *} P_{\text {genome }} \leq 0.01,{ }^{* * *} P_{\text {genome }} \leq 0.001$. All listed QTL have $P_{\text {chromosome }} \leq 0.05$. 


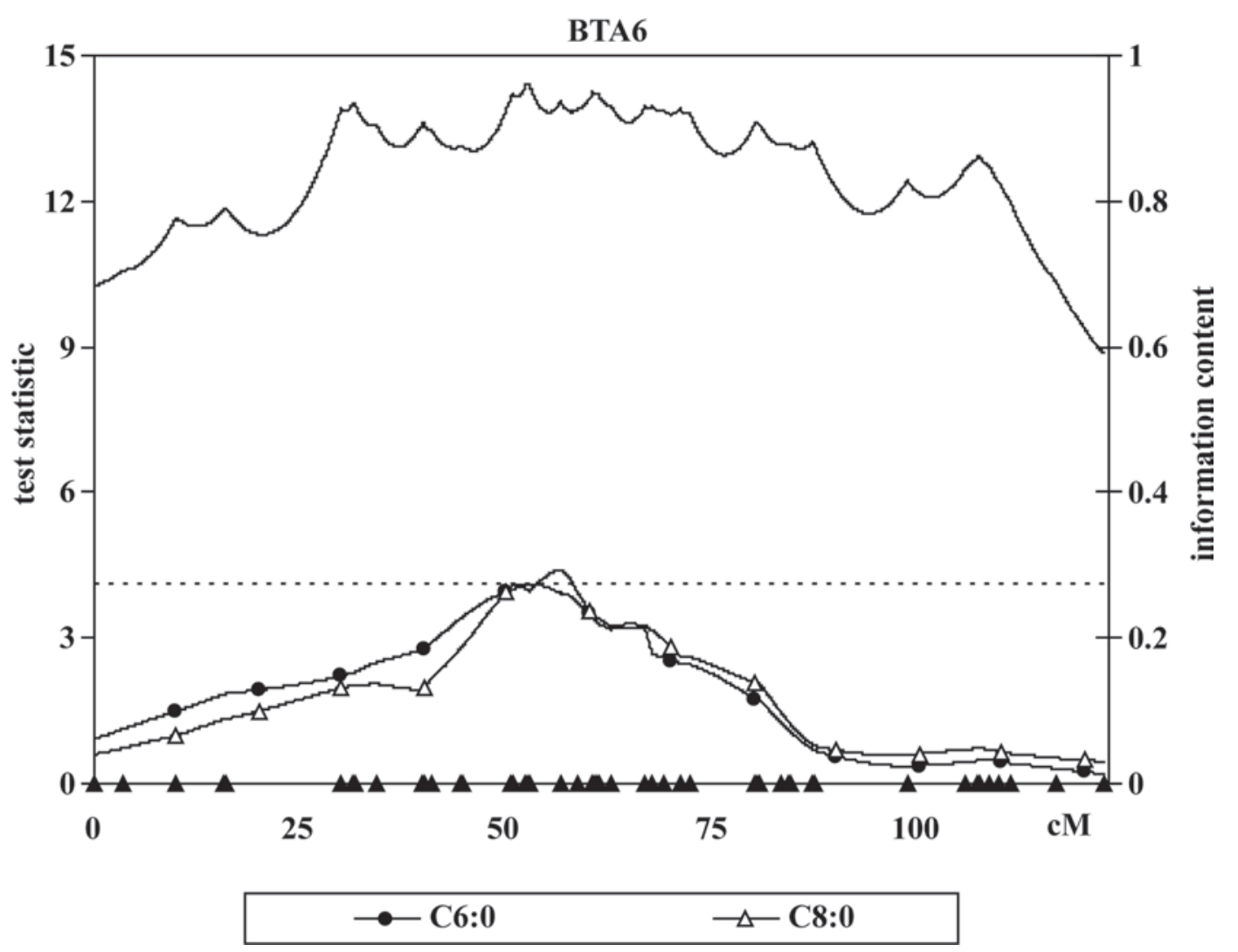

Figure 1. Test statistic for genome-wise significant QTL for C6:0 and C8:0 on Bos taurus autosome (BTA) 6. The dotted black line represents the genome-wise significance threshold. This threshold may vary slightly between traits and is shown only for the trait with the lowest genome-wise significance level. The solid black line represents the information content. The triangles on the x-axis represent the locations of the markers.

average effect of $0.7 \mathrm{SD}$. The difference between the 2 daughter groups for $\mathrm{C} 14: 0$ was $0.72(\mathrm{wt} / \mathrm{wt} \%)$ in family $2,0.28$ (wt/wt\%) in family 4, and 1.14 (wt/wt\%) in family 7. This QTL explained $4 \%$ of phenotypic variance in C14:0.

On BTA26, a QTL near the location of the SCD1 gene $(28 \mathrm{cM})$ affected all monounsaturated FA and their unsaturation indices (Table 2, Figure 4). The size of the QTL effect was about 0.7 phenotypic SD for all traits (Table 3 ). The allele that positively affected C10, $\mathrm{C} 12$, and C14 FA had a negative effect on C16 and C17 FA. Sires of families 1, 2, and 6 were heterozygous. In families 1 and 2, the QTL significantly affected all monounsaturated FA and unsaturation indices. Family 6 had only 29 offspring; therefore, not all QTL effects were significant. This QTL explained between 4 and $8 \%$ of phenotypic variance.

In addition to the significant QTL, 49 traits with suggestive QTL were found on 21 autosomes (Table 2). No QTL was found on BTA10, BTA12, BTA15, BTA18, BTA20, BTA23, BTA24, or BTA28. Although QTL were suggestive, some of these chromosomal regions were found for multiple traits that are known to overlap in synthesis pathways. For short, even-chain FA, suggestive QTL were found on 2 chromosomes; on BTA2 for $\mathrm{C} 4: 0$ and $\mathrm{C} 6: 0$, and on BTA29 for $\mathrm{C} 8: 0, \mathrm{C} 10: 0$, and C12:0. For odd-chain FA, suggestive QTL were found on 2 other chromosomes: on BTA21 for C5:0 and C7:0, and on BTA22 for C15:0 and C17:0. For several monounsaturated FA and unsaturation indices, there were suggestive QTL on BTA5, BTA11, and BTA13.

\section{Effect of DGAT1 and SCD1 Genotype Polymorphisms}

In a second analysis, data were adjusted for the effects of the DGAT1 K232A and SCD1 A293V genotypes, which resulted in complete disappearance of all linkage previously found on BTA14 and BTA26, except for the suggestive QTL for the C17 index on BTA14 (Table 2 ). This means that the detected QTL were most likely caused by the known mutations in DGAT1 and SCD1. After accounting for known mutations, however, a new suggestive QTL was found on BTA14 for C10:1, C12:1, and $\mathrm{C} 14: 1$ at approximately $50 \mathrm{cM}$, and for the $\mathrm{C} 12$ 
Table 3. Allele substitution effects and standard errors (subscript) within 7 paternal half-sib families for QTL on Bos taurus autosome (BTA) 6, BTA14, BTA19, and BTA26, and approximate phenotypic variation explained by QTL

\begin{tabular}{|c|c|c|c|c|c|c|c|c|}
\hline \multirow[b]{2}{*}{ Trait } & \multicolumn{7}{|c|}{ Family (no. of daughters) } & \multirow{2}{*}{$\begin{array}{c}\text { Phenotypic } \\
\text { variation } \\
\text { explained by } \\
\text { QTL }(\%)\end{array}$} \\
\hline & 1 (193) & $2(179)$ & $3(170)$ & $4(166)$ & $5(91)$ & $6(29)$ & $7(21)$ & \\
\hline \multicolumn{9}{|l|}{ BTA6 } \\
\hline C6:0 & $-0.08_{0.02} *$ & $0.03_{0.02}$ & $-0.03_{0.02}$ & $-0.01_{0.02}$ & $-0.05_{0.03}$ & $-0.10_{0.05} *$ & $0.04_{0.06}$ & 3 \\
\hline C8:0 & $-0.07_{0.02} *$ & $0.02_{0.02}$ & $-0.01_{0.02}$ & $-0.01_{0.02}$ & $-0.07_{0.02} *$ & $-0.03_{0.04}$ & $0.05_{0.05}$ & 3 \\
\hline \multicolumn{9}{|l|}{ BTA14 } \\
\hline C $7: 0$ & $-0.01_{0.00} *$ & $-0.01_{0.00} *$ & $-0.01_{0.00} *$ & $-0.01_{0.00} *$ & $-0.01_{0.00}$ & $0.01_{0.01}$ & $0.00_{0.01}$ & 6 \\
\hline C9:0 & $-0.01_{0.00} *$ & $0.00_{0.00}$ & $-0.01_{0.00} *$ & $-0.01_{0.00} *$ & $-0.01_{0.01}$ & $0.02_{0.01}^{0.01}$ & $-0.01_{0.01}$ & 7 \\
\hline C11:0 & $-0.01_{0.00} *$ & $-0.01_{0.00}$ & $-0.02_{0.01} *$ & $-0.02_{0.01} *$ & $-0.01_{0.01}$ & $0.02_{0.02}$ & $-0.01_{0.01}$ & 6 \\
\hline C14:0 & $0.43_{0.11} *$ & $0.59_{0.11} *$ & $0.35_{0.12} *$ & $0.35_{0.12} *$ & $-0.01_{0.23}$ & $0.65_{0.41}$ & $0.92_{0.32} *$ & 7 \\
\hline C15:0 & $-0.09_{0.03} *$ & $-0.03_{0.03}$ & $-0.11_{0.03} *$ & $-0.11_{0.03} *$ & $-0.10_{0.05}$ & $0.05_{0.10}$ & $-0.07_{0.08}$ & 5 \\
\hline C16:0 & $-1.63_{0.33} *$ & $-1.57_{0.34} *$ & $-1.34_{0.36} *$ & $-1.67_{0.35} *$ & $0.03_{0.66}$ & $-1.39_{1.19}$ & $-3.25_{0.92}$ * & 10 \\
\hline C16:1 & $-0.21_{0.04} *$ & $-0.30_{0.04} *$ & $-0.13_{0.05} *$ & $-0.32_{0.05} *$ & $0.13_{0.09}$ & $-0.19_{0.16}$ & $-0.20_{0.12}$ & 13 \\
\hline $\begin{array}{r}\text { BTA26 } \\
\text { C10:1 }\end{array}$ & $0.05_{0.01} *$ & $0.04_{0.01} *$ & $0.01_{0.01}$ & $0.01_{0.01}$ & $0.01_{0.01}$ & $0.03_{0.02}$ & $-0.03_{0.02}$ & 8 \\
\hline C14:1 & $0.18_{0.03} *$ & $0.16_{0.03} *$ & $0.00_{0.04}$ & $0.03_{0.04}$ & $0.08_{0.05}$ & $0.21_{0.09} *$ & $0.04_{0.09}$ & 6 \\
\hline C16:1 & $-0.22_{0.04} *$ & $-0.15_{0.04}^{*}$ & $0.03_{0.05}^{0.04}$ & $0.04_{0.05}$ & $0.08_{0.06}$ & $-0.04_{0.11}$ & $0.06_{0.12}$ & 5 \\
\hline C10 index & $1.26_{0.23} *$ & $0.93_{0.24} *$ & $0.04_{0.26}$ & $0.30_{0.26}$ & $0.44_{0.34}$ & $0.87_{0.64}$ & $-0.24_{0.69}$ & 5 \\
\hline C12 index & $0.30_{0.07} *$ & $0.26_{0.07} *$ & $0.01_{0.08}$ & $0.09_{0.08}$ & $0.15_{0.10}$ & $0.34_{0.19}$ & $0.22_{0.20}$ & 4 \\
\hline C14 index & $1.29_{0.23} *$ & $1.14_{0.23} *$ & $0.03_{0.25}$ & $0.30_{0.25}$ & $0.69_{0.32} *$ & $1.51_{0.62} *$ & $0.45_{0.67}$ & 6 \\
\hline C16 index & $-0.62_{0.11} *$ & $-0.45_{0.11} *$ & $0.07_{0.12}^{0.12}$ & $0.17_{0.11}$ & $0.29_{0.15}$ & $-0.14_{0.29}$ & $0.17_{0.31}^{0.01}$ & 6 \\
\hline C17 index & $-2.31_{0.36} *$ & $-1.69_{0.37} *$ & $0.19_{0.39}$ & $0.79_{0.39} *$ & $0.93_{0.51}$ & $-1.04_{0.97}$ & $0.79_{1.06}$ & 8 \\
\hline
\end{tabular}

*Significantly segregating QTL $(P \leq 0.05$, calculated by a $t$-test).

index at $73 \mathrm{cM}$. This suggestive QTL was also detected for several long-chain monounsaturated FA (see Schennink et al., 2009). Furthermore, precorrection for the $D G A T 1$ and $S C D 1$ genotypes resulted in additional suggestive QTL for the unsaturation indices of $\mathrm{C} 10$ to $\mathrm{C} 16$ on BTA19 and a significant QTL for C7:0 on BTA21. In total, 39 traits no longer showed significant linkage when correcting for DGAT1 and SCD1, of which 23 traits were located on BTA14 and BTA26, whereas 29 new traits with suggestive QTL were identified.

\section{DISCUSSION}

\section{Power Calculations}

In this study, we reported on suggestive QTL with $P_{\text {chromosome }}<0.05$ and significant QTL with $P_{\text {genome }}<$ 0.05. Based on power calculations on a daughter design of this size (Weller et al., 1990), there was a high $(>80 \%)$ power to identify QTL that explained at least $5 \%$ of phenotypic variance and a medium (about 50\%) power to identify QTL that explained 2.5 to $4.2 \%$ of phenotypic variance. The significant QTL found in this study explained 3 to $19 \%$ of phenotypic variance, which is in accordance with this expectation.

Adjusting the phenotypic data for effects of known genes reduces the residual variation in the traits and is therefore expected to result in a higher power to detect QTL (De Koning et al., 2001). In a second analysis, the phenotypic data were precorrected for the DGAT1 K232A and SCD1 A293V mutations. Several new suggestive QTL and 1 new significant QTL were detected. For some FA, including the previously found QTL on BTA6 and BTA19, the test statistic decreased below the threshold for suggestive QTL. In general, the change in test statistic was rather small $(<0.3)$.

\section{Fat Percentage}

In contrast to the limited research on FA proportions, fat percentage and fat yield have been studied extensively. A review by Khatkar et al. (2004) reported significant QTL for fat percentage and fat yield on BTA2, ВТА3, ВТА4, ВТА6, ВТА9, ВTA10, ВTA12, BTA14, BTA16, BTA20, and BTA26. The current study found one highly significant QTL for fat per- 


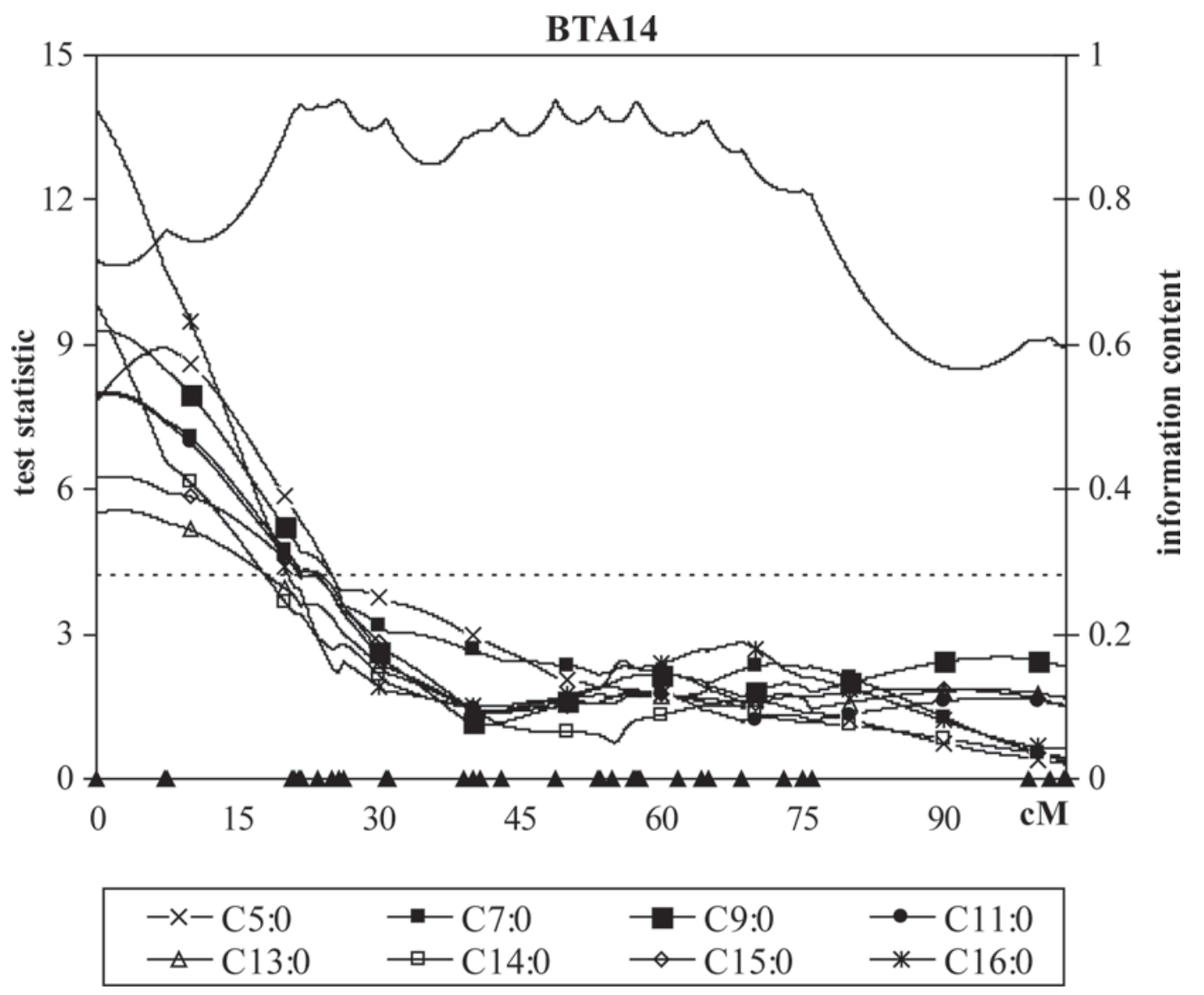

Figure 2. Test statistic for genome-wise significant QTL for saturated short- and medium-chain fatty acids on Bos taurus autosome (BTA) 14. The dotted black line represents the genome-wise significance threshold. This threshold may vary slightly between traits and is shown only for the trait with the lowest genome-wise significance level. The solid black line represents the information content. The triangles on the $\mathrm{x}$-axis represent the locations of the markers.

centage on BTA14 and 4 suggestive QTL on BTA6, BTA8, BTA13, and BTA27. The suggestive QTL on BTA6 is also mentioned in the review by Khatkar et al. (2004).

The current study found 4 significant QTL for shortand medium-chain FA on BTA6, BTA14, BTA19, and BTA26, and numerous suggestive QTL, which do not match the locations of the QTL for fat percentage that were detected. Finding different QTL for fat percentage and milk-fat composition was partly due to more detailed phenotyping of individuals. Milk-fat composition is not the same trait as milk-fat percentage. Although there is obviously a relationship between fat percentage and milk-fat composition, the genetic correlations between individual FA proportions and fat percentage differ largely between FA and range between 0.00 and 0.78 (Stoop et al., 2008). Some FA proportions increase with increasing fat percentage, whereas others decrease. These differences in size and sign of genetic correlations imply several genetic and physiological mechanisms with opposing effects, which might explain the presence of QTL for milk-fat composition that do not affect fat percentage.

\section{Fatty Acid Synthesis}

Several other studies have looked at candidate genes that were expected to play a role in milk-fat synthesis, such as PPARGC1A (Khatib et al., 2007), FAM13A1 (Cohen et al., 2004), and OPN on BTA6 (Schnabel et al., 2005; Khatib et al., 2007); DGAT1 on BTA14 (Schennink et al., 2007); GH (Viitala et al., 2006), FASN (Smith, 1994), and STAT5A on BTA19 (Stephens et al., 1999; Brym et al., 2004); and SCD1 on BTA26 (Schennink et al., 2008). Although most studies reported effects on fat percentage, data on milk-fat composition were not available, except for those of Schennink et al. (2007, 2008). In fact, only very few studies have reported effects on fat composition, mainly in adipose tissue of beef cattle (Reh et al., 2004; Taniguchi et al., 2004; Moioli et al., 2007; Morris et al., 2007; Zhang et al., 2008). 


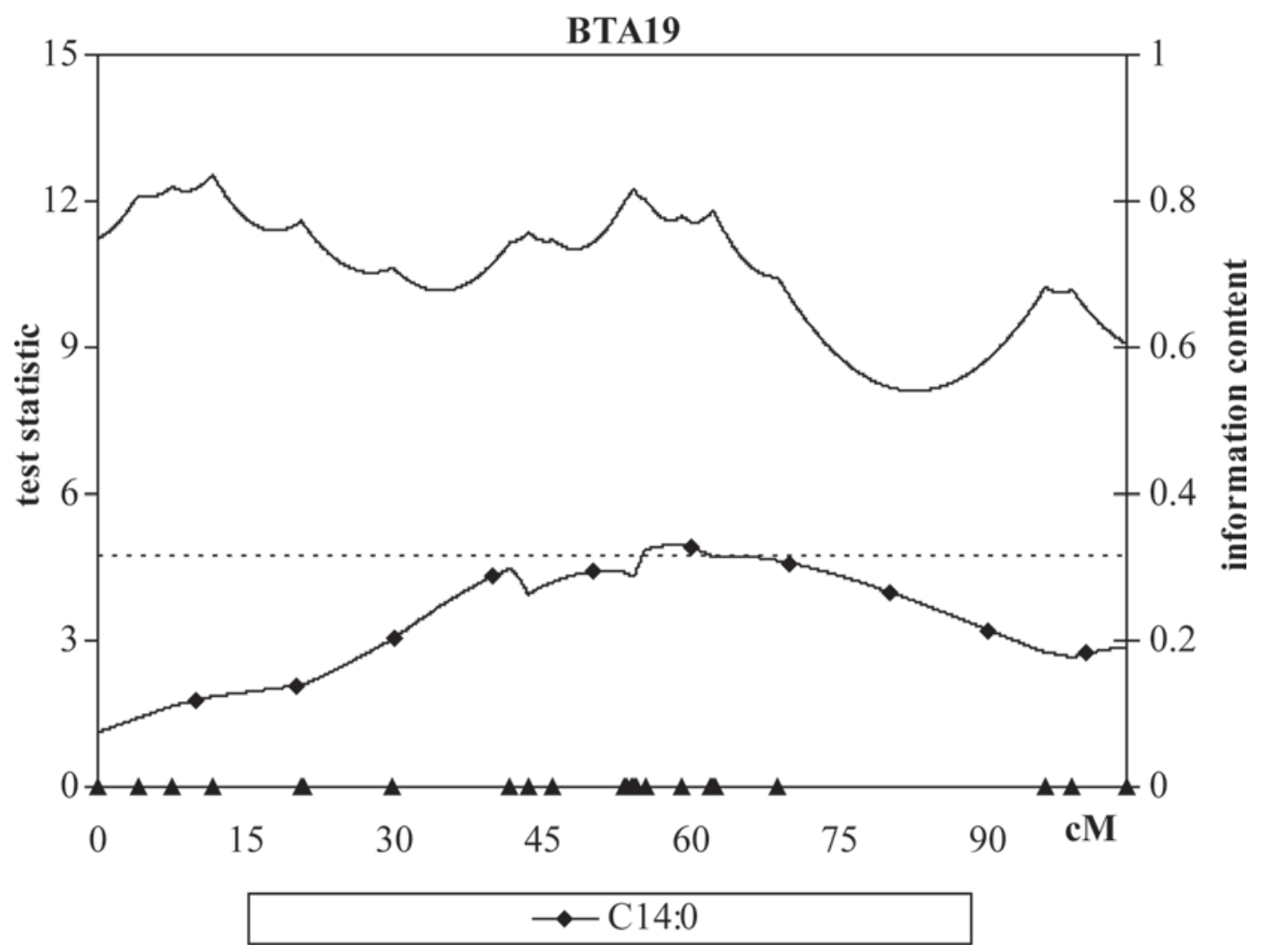

Figure 3. Test statistic for genome-wise significant QTL for C14:0 on Bos taurus autosome (BTA) 19. The dotted black line represents the genome-wise significance threshold. The solid black line represents the information content. The triangles on the $\mathrm{x}$-axis represent the locations of the markers.

Strong evidence was found for significant QTL on BTA14 and BTA26. These QTL effects are likely caused by DGAT1 (BTA14) and SCD1 (BTA26), because these QTL disappear after correction for the DGAT1 and SCD1 genotypes. The $\mathrm{C} 10$ to $\mathrm{C} 18 \mathrm{FA}$ can be desaturated by SCD1 (Enoch et al., 1976; Chung et al., 2000), and sequentially, all present individual FA can be esterified to glycerol via GPAT (Roy et al., 2006a), AGPAT (Mistry and Medrano, 2002), and DGAT1 (Winter et al., 2002) to end up as triacylglycerols in the milk.

A significant QTL for C6:0 and C8:0 was found on BTA6 at approximately $55 \mathrm{cM}$, which is in near proximity to the PPARGC1A gene. The PPARGC1A gene is one of several major transcription factors that has been proposed to play a central role in regulation of milk-fat synthesis activity in the mammary gland (Khatib et al., 2007; Bernard et al., 2008). The PPARGC1A gene is involved in up- and downregulation of several genes of the acetyl-CoA cycle, such as acetyl-CoA carboxylase, which activates acetyl-CoA (ACC; Barber et al., 1997; Mao et al., 2001) and fatty acid synthase (FASN; Smith, 1994).
A significant QTL for C14:0 was found on BTA19. Morris et al. (2007) reported a significant effect of the candidate gene FASN (BTA19) on C14:0. Within the acetyl-CoA cycle, chain elongation is initiated by acyltransferase, 1 of the 6 enzymes associated with FASN, which loads mainly acetyl and malonyl substrates to $\beta$-ketoacylsynthase (Roy et al., 2005). Regulation of chain termination for $\mathrm{C} 14: 0$ and $\mathrm{C} 16: 0$ is done by thioesterase I, another enzyme associated with FASN (Smith, 1994). The FASN gene, in particular the thioesterase I enzyme, might be a good candidate for the detected QTL on BTA19 in the present study. However, at least 2 other genes in the proximity of the QTL have been associated with fat synthesis, and could also be responsible for the observed QTL effect: $G H$ and STAT5A (Brym et al., 2004; Viitala et al., 2006). The STAT5 gene mediates a prolactin signal and stimulates promoter III of acetyl-CoA carboxylase (Rosen et al., 1999; Mao et al., 2002), and can in turn be stimulated by GH and IGF1 (Yang et al., 2000).

Several QTL were identified for short- or mediumchain FA: for C4:0 and C6:0, a suggestive QTL was found on BTA2, for C6:0 and C8:0 on BTA6, for C14:0 


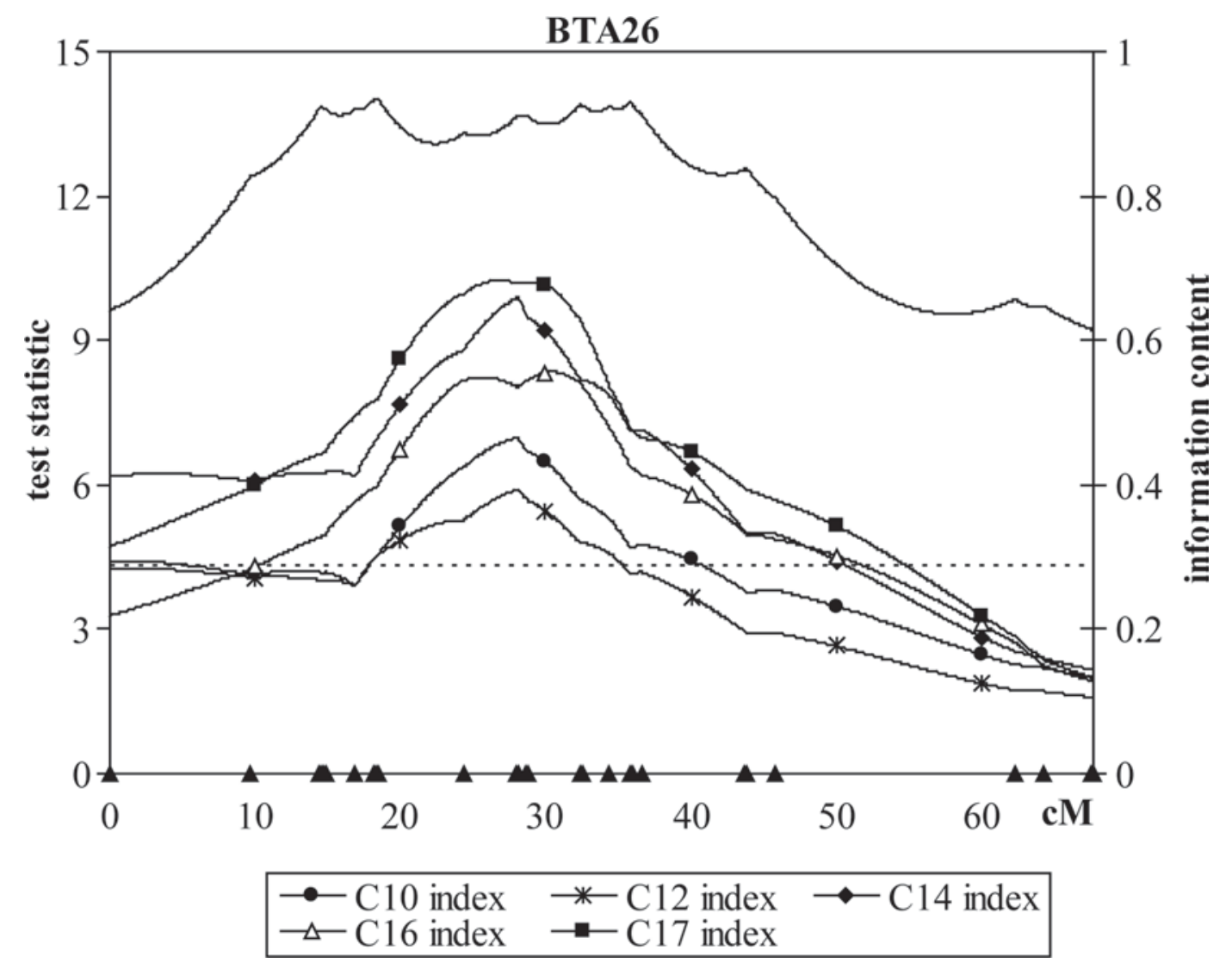

Figure 4. Test statistic for genome-wide significant QTL for unsaturation indices on Bos taurus autosome (BTA) 26. The dotted black line represents the genome-wise significance threshold. This threshold may vary slightly between traits and is shown only for the trait with the lowest genome-wise significance level. The solid black line represents the information content. The triangles on the $\mathrm{x}$-axis represent the locations of the markers.

on BTA19, and for C8:0, C10:0, and C12:0 on BTA29 (suggestive). Although these chromosomes harbor genes that have been related to milk-fat synthesis, additional mapping at higher resolutions will be necessary to reduce the size of confidence intervals and identify possible candidate genes. Increasing the number of SNP, especially in currently sparse regions such as the 70 to $95 \mathrm{cM}$ region on BTA19, will improve the information content of the linkage map.

\section{CONCLUSIONS}

Four distinct significant QTL were identified that affected short- and medium-chain FA. Two QTL affected C6:0 and C8:0 (BTA6) and C14:0 (BTA19). The other 2 QTL were most likely caused by DGAT1 (BTA14) and SCD1 (BTA26). These 4 QTL explain 3 to $19 \%$ of phenotypic variance in the affected traits. In total, 49 suggestive QTL were reported that affect either evenchain FA, odd-chain FA, or monounsaturated FA and unsaturation indices.

Quantitative trait loci that affect specific FA might increase the understanding of physiological processes involved in fat synthesis and may aid in locating the underlying genes. Selection might be used to decrease proportions of unfavorable FA in bovine milk, such as C16:0, and reduce the fat melting point for more spreadable butter.

\section{ACKNOWLEDGMENTS}

This study was part of the Milk Genomics Initiative, funded by Wageningen University, NZO (Dutch Dairy Association, Zoetermeer, the Netherlands), the breeding company CRV (Arnhem, the Netherlands), and the technology foundation STW (Utrecht, the Netherlands). The authors thank the owners of the herds, Richard Spelman for his work on the QTL program, and Patrick Koks for his work on the genetic map.

\section{REFERENCES}

Barber, M. C., R. A. Clegg, M. T. Travers, and R. G. Vernon. 1997. Lipid metabolism in the lactating mammary gland. Biochim. Biophys. Acta 1347:101-126.

Bernard, L., C. Leroux, and Y. Chilliard. 2008. Expression and nutritional regulation of lipogenic genes in the ruminant lactating 
mammary gland. Pages 67-108 in Bioactive Components of Milk. Z. Bosze, ed. Springer, New York, NY.

Bobe, G., J. A. Minick-Bormann, G. L. Lindberg, A. E. Freeman, and D. C. Beitz. 2008. Short communication: Estimates of genetic variation of milk-fatty acids in US Holstein cows. J. Dairy Sci. 91:1209-1213.

Brym, P., S. Kaminski, and A. Rusc. 2004. New SSCP polymorphism within bovine STAT5A gene and its associations with milk performance traits in Black-and-White and Jersey cattle. J. Appl. Genet. 45:445-452.

Chung, M., S. Ha, S. Jeong, J. Bok, K. Cho, M. Baik, and Y. Choi. 2000. Cloning and characterization of bovine stearoyl CoA desaturase cDNA from adipose tissues. Biosci. Biotechnol. Biochem. 64:1526-1530.

Churchill, G. A., and R. W. Doerge. 1994. Empirical threshold values for quantitative trait mapping. Genetics 138:963-971.

Clarke, S. D. 1993. Regulation of fatty acid synthase gene expression: An approach for reducing fat accumulation. J. Anim. Sci. 71:1957-1965

Cohen, M., M Reichenstein, A. Everts-van der Wind, J. Heon-Lee, M. Shani, H. A. Lewin, J. I. Weller, M. Ron, and E. Seroussi. 2004. Cloning and characterization of FAM13A1-A gene near a milk protein QTL on BTA6: Evidence for population-wide linkage disequilibrium in Israeli Holsteins. Genomics 84:374-383.

De Koning, D. J., N. F. Schulman, K. Elo, S. Moisio, R. Kinos, J. Vilkki, and A. Maki-Tanila. 2001. Mapping of multiple quantitative trait loci by simple regression in half-sib designs. J. Anim. Sci. 79:616-622.

De Koning, D. J., P. M. Visscher, S. A. Knott, and C. S. Haley. 1998 A strategy for QTL detection in half-sib populations. Anim. Sci. 67:257-268.

Enoch, H. G., A. Catala, and P. Strittmatter. 1976. Mechanism of rat liver microsomal stearyl-CoA desaturase. Studies of the substrate specificity, enzyme-substrate interactions, and the function of lipid. J. Biol. Chem. 251:5095-5103.

Falaki, M., A. Prandi, C. Corradini, M. Sneyers, N. Gengler, S. Massart, U. Fazzini, A. Burny, D. Portetelle, and R. Renaville. 1997. Relationships of growth hormone gene and milk protein polymorphisms to milk production traits in Simmental cattle. J. Dairy Res. 64:47-56.

German, J. B., and C. J. Dillard. 2006. Composition, structure and absorption of milk lipids: A source of energy, fat-soluble nutrients and bio-active molecules. Crit. Rev. Food Sci. Nutr. 46:57-92.

Gilmour, A.R., B.J. Gogel, B.R. Cullis, S.J. Welham, R. Thompson. 2002. ASReml User Guide Release 1.0. VSN Int. Ltd., Hemel Hempstead, UK.

Green, P., K. Falls, and S. Crooke. 1990. Documentation for CRI-MAP. Version 2.4. Washington School of Medicine, St. Louis, MO.

Jensen, R. G. 2002. Invited Review: The composition of bovine milk lipids: January 1995 to December 2000. J. Dairy Sci. 85:295350.

Kelsey, J. A., B. A. Corl, R. J. Collier, and D. E. Bauman. 2003 The effect of breed, parity, and stage of lactation on conjugated linoleic acid (CLA) in milk-fat from dairy cows. J. Dairy Sci. 86:2588-2597.

Khatib, H., I. Zaitoun, J. Wiebelhaus-Finger, Y. M. Chang, and G. J. M. Rosa. 2007. The association of bovine PPARGC1A and $O P N$ genes with milk composition in two independent Holstein cattle populations. J. Dairy Sci. 90:2966-2970.

Khatkar, M. S., P. C. Thomson, I. Tammen, and H. W. Raadsma. 2004. Quantitative trait loci mapping in dairy cattle: Review and meta-analysis. Genet. Sel. Evol. 36:163-190.

Knott, S. A., J. M. Elsen, and C. S. Haley. 1996. Methods for multiplemarker mapping of quantitative trait loci in half-sib populations. Theor. Appl. Genet. 93:71-80.

Lander, E., and L. Kruglyak. 1995. Genetic dissection of complex traits: Guidelines for interpreting and reporting linkage results. Nat. Genet. 11:241-247.

MacGibbon, A. K. H., and M. W. Taylor. 2006. Composition and structure of bovine milk lipids. Advanced Dairy Chemistry. Vol.
2: Lipids. 3rd ed. P. F. Fox and P. L. H. McSweeney, ed. Springer, New York, NY.

Mao, J., S. Marcos, S. K. Davis, J. Burzlaff, and H. M. Seyfert. 2001. Genomic distribution of three promoters of the bovine gene encoding acetyl-CoA carboxylase alpha and evidence that the nutritionally regulated promoter I contains a repressive element different from that in rat. Biochem. J. 358:127-135.

Mao, J., A. J. Molenaar, T. T. Wheeler, and H. M. Seyfert. 2002. STAT5 binding contributes to lactational stimulation of promoter III expressing the bovine acetyl-CoA carboxylase alpha-encoding gene in the mammary gland. J. Mol. Endocrinol. 29:73-88.

Mistry, D. H., and J. F. Medrano. 2002. Cloning and localization of the bovine and ovine lysophosphatidic acid acyltransferase ( $L P A A T)$ genes that codes for an enzyme involved in triglyceride biosynthesis. J. Dairy Sci. 85:28-35.

Moioli, B., G. Contarini, A. Avalli, G. Catillo, L. Orru, G. De Matteis, G. Masoero, and F. Napolitano. 2007. Short communication: Effect of stearoyl-coenzyme A desaturase polymorphism on fatty acid composition of milk. J. Dairy Sci. 90:3553-3558.

Morris, C. A., N. G. Cullen, B. C. Glass, D. L. Hyndman, T. R Manley, S. M. Hickey, J. C. McEwan, W. S. Pitchford, C. D. K. Bottema, and M. A. H. Lee. 2007. Fatty acid synthase effects on bovine adipose fat and milk-fat. Mamm. Genome 18:64-74.

Reh, W. A., E. A. Maga, N. M. B. Collette, A. Moyer, J. S. ConradBrink, S. J. Taylor, E. J. DePeters, S. Oppenheim, J. D. Rowe, R. H. BonDurant, G. B. Anderson, and J. D. Murray. 2004. Hot topic: Using a stearoyl-CoA desaturase transgene to alter milk-fatty acid composition. J. Dairy Sci. 87:3510-3514.

Rosen, E. D., P. Sarraf, A. E. Troy, G. Bradwin, K. Moore, D. S Milstone, B. M. Spiegelman, and R. M. Mortensen. 1999. PPAR is required for the differentiation of adipose tissue in vivo and in vitro. Mol. Cell 4:611-617.

Roy, R., L. Ordovas, S. Taourit, P. Zaragoza, A. Eggen, and C. Rodellar. 2006a. Genomic structure and an alternative transcript of bovine mitochondrial glycerol-3-phosphate acyltransferase gene (GPAM). Cytogenet. Genome Res. 112:82-89.

Roy, R., L. Ordovas, P. Zaragoza, A. Romero, C. Moreno, J. Altarriba, and C. Rodellar. 2006b. Association of polymorphisms in the bovine FASN gene with milk-fat content. Anim. Genet. 37:215-218.

Roy, R., S. Taourit, P. Zaragoza, A. Eggen, and C. Rodellar. 2005. Genomic structure and alternative transcript of bovine fatty acid synthase gene $(F A S N)$ : Comparative analysis of the FASN gene between monogastric and ruminant species. Cytogenet. Genome Res. 111:65-73.

SAS Institute. 2004. SAS 9.1 National Language Support (NLS): User's Guide. SAS Inst. Inc., Cary, NC.

Schennink, A., J. M. L. Heck, H. Bovenhuis, M. H. P. W. Visker, H. J. F. van Valenberg, and J. A. M. van Arendonk. 2008. Milk-fatty acid unsaturation: Genetic parameters and effects of stearoyl-CoA desaturase $(S C D 1)$ and acyl CoA:diacylglycerol acyltransferase 1 (DGAT1). J. Dairy Sci. 91:2135-2143.

Schennink, A., W. M. Stoop, M. H. P. W. Visker, J. M. L. Heck, H. Bovenhuis, J. J. van der Poel, H. J. F. van Valenberg, and J. A M. van Arendonk. 2007. DGAT1 underlies large genetic variation in milk-fat composition of dairy cows. Anim. Genet. 38:467-473.

Schennink, A., W. M. Stoop, M. H. P. W. Visker, J. J. van der Poel, H. Bovenhuis, and J. A. M. van Arendonk. 2009. Genome-wide scan for bovine milk-fat composition. II. Quantitative trait loci for long-chain fatty acids. J. Dairy Sci. 92:4676-4682.

Schnabel, R. D., J. Kim, M. S. Ashwell, T. S. Sonstegard, C. P. van Tassell, E. E. Connor, and J. F. Taylor. 2005. Fine-mapping milk production quantitative trait loci on BTA6: Analysis of the bovine osteopontin gene. Proc. Natl. Acad. Sci. USA 102:6896-6901.

Schopen, G. C. B., P. D. Koks, J. A. M. van Arendonk, H. Bovenhuis, and M. H. P. W. Visker. 2009. Whole genome scan to detect QTL for bovine milk protein composition. Anim. Genet. In press.

Smith, S. 1994. The animal fatty acid synthase: One gene, one polypeptide, seven enzymes. FASEB J. 8:1248-1259.

Soyeurt, H., P. Dardenne, A. Gillon, C. Croquet, S. Vanderick, P. Mayeres, C. Bertozzi, and N. Gengler. 2006. Variation in fatty acid 
contents of milk and milk-fat within and across breeds. J. Dairy Sci. 89:4858-4865.

Soyeurt, H., A. Gillon, S. Vanderick, P. Mayeres, C. Bertozzi, and N. Gengler. 2007. Estimation of heritability and genetic correlations for the major fatty acids in bovine milk. J. Dairy Sci. 90:44354442.

Spelman, R. J., W. Coppieters, L. Karim, J. A. M. van Arendonk, and H. Bovenhuis. 1996. Quantitative trait loci analysis for five milk production traits on chromosome six in the Dutch HolsteinFriesian population. Genetics 144:1799-1808.

Stephens, J. M., R. F. Morrison, Z. Wu, and S. R. Farmer. 1999 PPAR $\gamma$ Ligand-dependent induction of STAT1, STAT5A, and STAT5B during adipogenesis. Biochem. Biophys. Res. Commun. 262:216-222.

Stoop, W. M., J. A. M. van Arendonk, J. M. L. Heck, H. J. F. van Valenberg, and H. Bovenhuis. 2008. Genetic parameters for major milk-fatty acids and milk production traits of Dutch HolsteinFriesians. J. Dairy Sci. 91:385-394.

Taniguchi, M., T. Utsugi, K. Oyama, H. Mannen, M. Kobayashi, Y. Tanabe, A. Ogino, and S. Tsuji. 2004. Genotype of stearoyl-CoA desaturase is associated with fatty acid composition in Japanese Black cattle. Mamm. Genome 15:142-148.

Viitala, S., J. Szyda, S. Blott, N. Schulman, M. Lidauer, A. MakiTanila, M. Georges, and J. Vilkki. 2006. The role of bovine growth hormone receptor and prolactin receptor genes in milk, fat and protein production in Finnish Ayrshire dairy cattle. Genetics $173: 2151-2164$.

Visscher, P. M., R. Thompson, and C. S. Haley. 1996. Confidence intervals in QTL mapping by bootstrapping. Genetics 143:10131020.

Vlaeminck, B., V. Fievez, A. R. J. Cabrita, A. J. M. Fonseca, and R. J. Dewhurst. 2006. Factors affecting odd- and branched-chain fatty acids in milk: A review. Anim. Feed Sci. Technol. 131:389-417.

Weller, J. I., Y. Kashi, and M. Soller. 1990. Power of daughter and granddaughter designs for determining linkage between marker loci and quantitative trait loci in dairy cattle. J. Dairy Sci. $73: 2525-2537$.

Winter, A., W. Kramer, F. A. Werner, S. Kollers, S. Kata, G. Durstewitz, J. Buitkamp, J. E. Womack, G. Thaller, and R. Fries. 2002. Association of a lysine-232/alanine polymorphism in a bovine gene encoding acyl-CoA:diacylglycerol acyltransferase (DGAT1) with variation at a quantitative trait locus for milk-fat content. Proc. Natl. Acad. Sci. USA 99:9300-9305.

Yang, J., J. J. Kennelly, and V. E. Baracos. 2000. The activity of transcription factor Stat5 responds to prolactin, growth hormone, and IGF-I in rat and bovine mammary explant culture. J. Anim. Sci. 78:3114-3125.

Zhang, S., T. J. Knight, J. M. Reecy, and D. C. Beitz. 2008. DNA polymorphisms in bovine fatty acid synthase are associated with beef fatty acid composition. Anim. Genet. 39:62-70. 